\title{
Mantled fungal reproductive units in land plant tissue from the Lower Devonian Rhynie chert
}

\author{
MICHAEL KRINGS \& THOMAS N. TAYLOR
}

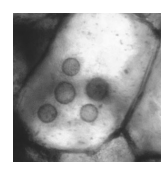

\begin{abstract}
Multiple specimens of a conspicuous fungal reproductive unit occur in land plant tissue preserved in the Lower Devonian Rhynie chert. The reproductive units consist of a walled sphere (up to $32 \mu \mathrm{m}$ in diameter) borne terminally on a tubular hypha. Some $50 \%$ of specimens are enveloped in a prominent mantle constructed of thin-walled interlaced hyphae; hyphal tips are club-shaped. The clustered units are in turn embedded in a loose meshwork of thin-walled hyphae, some of which appear to have contributed in mantle formation. The systematic affinities of this reproductive unit remain unknown, however, it differs from all mantled fungal reproductive units previously described from the Rhynie chert. This discovery supports the hypothesis that multiple fungi existed in the Early Devonian that produced various types of hyphal mantles. - Key words: biodiversity, fossil fungi, hyphal investment, reproductive biology.
\end{abstract}

KRINGS, M. \& TAYLOR, T.N. 2015. Mantled fungal reproductive units in land plant tissue from the Lower Devonian Rhynie chert. Bulletin of Geosciences 90(1), 1-6 (1 figure). Czech Geological Survey, Prague. ISSN 1214-1119. Manuscript received May 26, 2014; accepted in revised form October 6, 2014; published online November 25, 2014; issued January 26, 2015.

\begin{abstract}
Michael Krings (corresponding author), Department für Geo- und Umweltwissenschaften, Paläontologie und Geobiologie, Ludwig-Maximilians-Universität, and Bayerische Staatssammlung für Paläontologie und Geologie, Richard-Wagner-Straße 10, 80333 Munich, Germany; m.krings@lrz.uni-muenchen.de・Thomas N. Taylor, Department of Ecology and Evolutionary Biology, and Natural History Museum and Biodiversity Research Institute, The University of Kansas, Lawrence, Kansas 66045, USA; tntaylor@ku.edu
\end{abstract}

Fungi today are abundant and diverse. Because they function as decomposers, are effective as parasites and disease causative agents, and enter into mutualistic associations with a wide variety of other organisms, fungi can profoundly affect the structure and organization of the ecosystems in which they live (Dighton 2003). Although it is generally assumed that fungi were comparably diverse and played similar roles in the ecosystems of the geologic past, direct evidence from the fossil record is rare. Few fossil localities provide direct insights into the paleobiodiversity of fungi, with the most important of these being the Lower Devonian Rhynie chert in Aberdeenshire, Scotland. This famous Lagerstätte has yielded numerous exquisitely preserved fungal fossils, including several examples of fungal associations and interactions with plants that have been documented in great detail and compared to modern analogues (surveyed in Taylor et al. 2004, 2014). Despite these reports, the vast majority of fungal fossils from the Rhynie chert remain understudied to date. As a result, fungal biodiversity in the Rhynie ecosystem continues to be incompletely documented, resulting in numerous gaps in our understanding of the roles of fungi in early continental ecosystems.

In particular, the numerous microscopic fungal reproductive units (e.g., spores, resting spores, sporangia), which occur dispersed or in association with land plant tissue in next to every Rhynie chert thin section, have received little attention following the initial description of several forms by Kidston \& Lang (1921). The fossils differ in size, wall thickness, and in some instances mode of attachment (e.g., Krings et al. 2014). The large number of different forms suggests that there may be a substantial, unrealized fungal biodiversity in the Rhynie ecosystem. Unfortunately, few of these fossils exhibit distinctive features that allow for their precise systematic placement.

Three fungal reproductive units that have recently been documented from the Rhynie chert differ from the others in the possession of an ancillary surface covering termed a hyphal mantle (Krings \& Taylor 2013, 2014a; Krings et al. 2014). The presence of a hyphal mantle is not in itself a diagnostic feature because such coverings are known to occur in several groups of fungi. Nevertheless, the Rhynie chert fossils are important since they represent the oldest evidence of hyphal mantles in fungal reproductive units (Krings \& Taylor 2013). Moreover, mantle morphology differs considerably among the three forms, suggesting that the mantle may be used as a complementary structural feature in assessing fungal diversity in the Rhynie ecosystem. 
Here we describe a fourth type of mantled fungal reproductive unit from the Rhynie chert that is considerably smaller than those recorded previously. This form occurs principally as an intracellular colonizer of land plant cortical tissue, and represents a significant piece of new information about fungi producing hyphal coverings in the Early Devonian.

\section{Geological setting, material, and methods}

The Rhynie chert locality is situated northwest of the village of Rhynie, Aberdeenshire, Scotland. The so-called Rhynie Block in the northern part of the Rhynie Outlier consists of an extensive sequence of sedimentary and volcanic rocks. The fossil-bearing cherts occur in the Windyfield Shales Member, i.e. within the lower part of the Dryden Flags Formation (Parry et al. 2011). This Lagerstätte is made up of fossiliferous beds containing lacustrine shales and cherts that have been interpreted as a series of ephemeral freshwater pools which existed within a hot spring environment (Rice et al. 2002, Rice \& Ashcroft 2004). Preserved within the cherts are both aquatic (freshwater) facies from the pools and subaerial soil/litter horizons with in situ plants that are thought to have grown along the margins of the pools. Preservation of the biota is interpreted as being a result of temporary flooding of silica-rich water, or by groundwater high in silica percolating to the surface (Powell et al. 2000). The cherts have been dated as Pragian-? earliest Emsian based on spore assemblages (Wellman 2006, Wellman et al. 2006). High-precision age constraints on the Rhynie Lagerstätte indicate absolute ages of $407.1 \pm 2.2 \mathrm{Ma}$ (Mark et al. 2011) and 411.5 $\pm 1.3 \mathrm{Ma}$ (Parry et al. 2011).

The specimens were identified in a thin section prepared by cementing a wafer of the Rhynie chert to a glass slide and then grinding the rock slice until the section was sufficiently thin to transmit light. The slide is deposited in the Bayerische Staatssammlung für Paläontologie und Geologie (Munich, Germany) under accession number SNSB-BSPG 2013 XV 24. Specimens were analyzed using normal transmitted light microscopy; digital images were captured with a Leica DFC-480 camera.

\section{Description}

The reproductive units occur singly (e.g., Fig. 1B) or in clusters of $5->25$ individuals (Fig. 1A-C) within several cells of a largely intact piece $(\sim 3 \times 4 \mathrm{~mm}$ large $)$ of thin-walled land plant axial cortical tissue. The reproductive units are globose and between 22 and 30( 32) $\mu \mathrm{m}$ in diameter. All are composed of a central cavity that is bounded on the outside by a distinct wall that varies in thickness among specimens. The central cavity has a diameter of $(<10-) 15-18(-20) \mu \mathrm{m}$ and most specimens are empty; however, in some occurs a (sub)centrically positioned mass of apparently congealed contents (Fig. 1D, E).

Approximately $50 \%$ of the specimens are enveloped in a prominent hyphal mantle up to $6(-7) \mu \mathrm{m}$ thick (Fig. 1G-K), while others lack evidence of the presence of any ancillary covering (Fig. 1D, F). One specimen shows what appears to be a translucent surface sheathing (large black arrow in Fig. 1E), but this may represent a preservation artifact resulting from shrinkage of the specimen during fossilization. The mantle occurs in the form of a one- to incompletely two-storied system of branched, irregularly swollen and constricted, densely interlaced hyphae, which are thin-walled, translucent, and between $<2$ and $4 \mu \mathrm{m}$ wide; septa appear to be lacking. All mantle hyphae extend around the circumference of the structure (Fig. 1Ib-K); hyphal tips are slightly swollen to club-shaped (black arrows in Fig. 1Ia). The mantled specimens that occur in clusters are additionally surrounded by a loose meshwork of thin-walled, sparsely septate hyphae (Fig. 1G-I). Some of these hyphae resemble mantle hyphae, but most are narrower and tubular (e.g., white arrows in Fig. $1 \mathrm{H}$ and Ia, black arrow in Fig. 1Ib). In surface view of the mantle, the physical connections between the tubular and mantle hyphae are sometimes recognizable as circular demarcations (white arrows in Fig. 1IJ).

The wall surrounding the central cavity ranges in thickness from 1 to $2.1 \mu \mathrm{m}$ and appears to be a single layer. Narrow radial files of opaque material are irregularly distributed within the wall (arrows in Fig. 1J). Moreover, some specimens suggest that the individual mantle hyphae fuse with or penetrate the wall (e.g., arrow in Fig. 1K).

The subtending hyphae of specimens occurring singly are typically tubular and $\sim 1.5(-2) \mu \mathrm{m}$ wide; septa appear to

Figure 1. Mantled fungal reproductive unit from the Lower Devonian Rhynie chert. $\bullet$ A, B - clusters of specimens in host cells. Bars $=100 \mu \mathrm{m} . \cdot \mathrm{C}-\mathrm{de}-$ tail of Fig. 1B, co-occurrence of mantled (upper right of image) and naked (lower left of image) specimens in host cell. Bar $=20 \mu \mathrm{m}$. $\bullet \mathrm{D}-\mathrm{F}-\mathrm{specimens}$ lacking hyphal mantles. Black arrow in Fig. 1D and lower black arrow in Fig. 1E: septa. White arrow in Fig. 1E: bulbous swelling of subtending hypha. Upper black arrow in Fig. 1E: translucent surface sheathing. Bars $=10 \mu \mathrm{m}$. $\bullet \mathrm{G}-$ cluster of mantled units. Bar $=10 \mu \mathrm{m}$. $\bullet \mathrm{H}-$ three units and meshwork hypha (white arrow). Black arrow: bulbous swelling or mantle hypha in cross section. Bar $=10 \mu \mathrm{m}$. $\bullet$ I - cluster of mantled specimens. Fig. 1 Ia: normal light. Fig. 1Ib: same cluster as in Fig. 1Ia, reversed light, slightly different focal plane. White arrows in Fig. 1Ia: tubular meshwork hyphae, black arrows: club-shaped tips of mantle hyphae. White arrows in Fig. 1Ib: physical connections between meshwork and mantle hyphae, black arrow: meshwork hypha. Bars $=10 \mu \mathrm{m} . \bullet \mathrm{J}, \mathrm{K}-$ mantle morphology. Arrows in Fig. 1J: radial files of opaque matter in wall. White arrow in Fig. 1K: mantle hypha apparently merging with or penetrating wall. Bars $=10 \mu \mathrm{m}$. 
Michael Krings \& Thomas N. Taylor • Mantled fungal reproductive units in land plant tissue from the Lower Devonian Rhynie chert
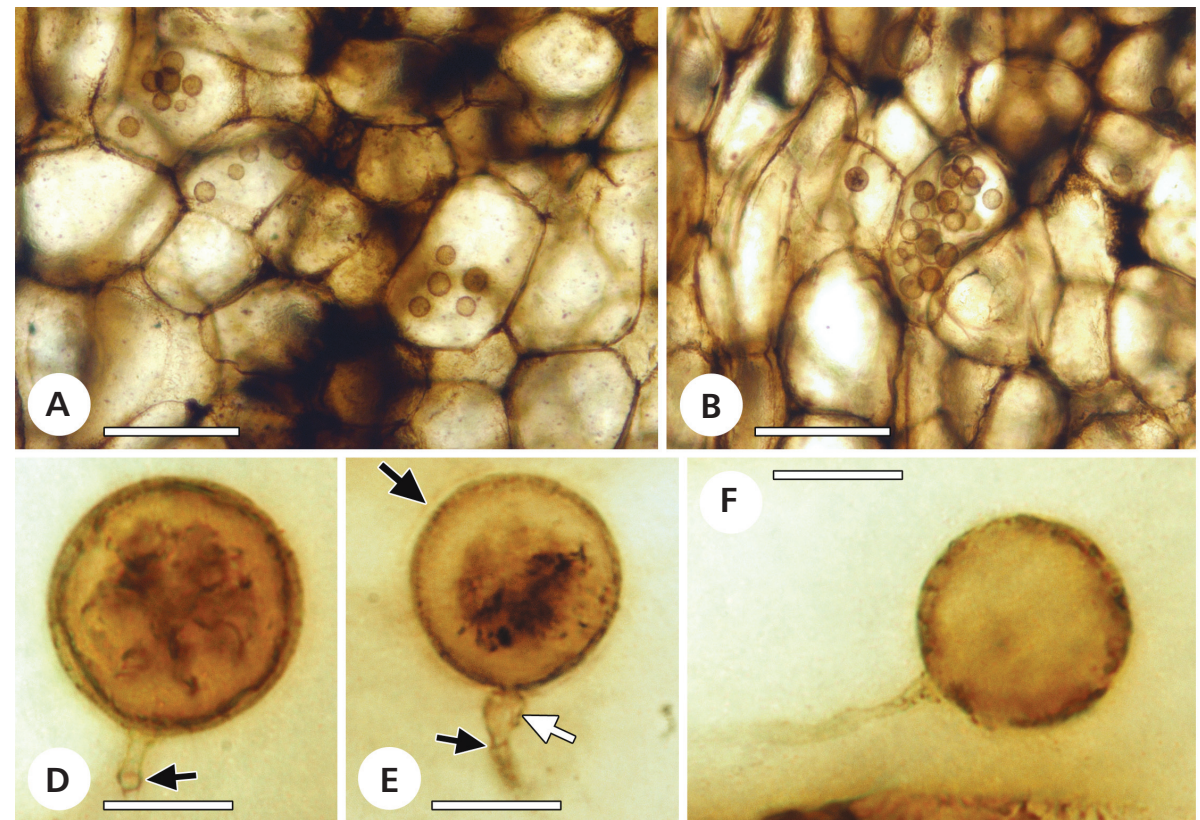

$F$
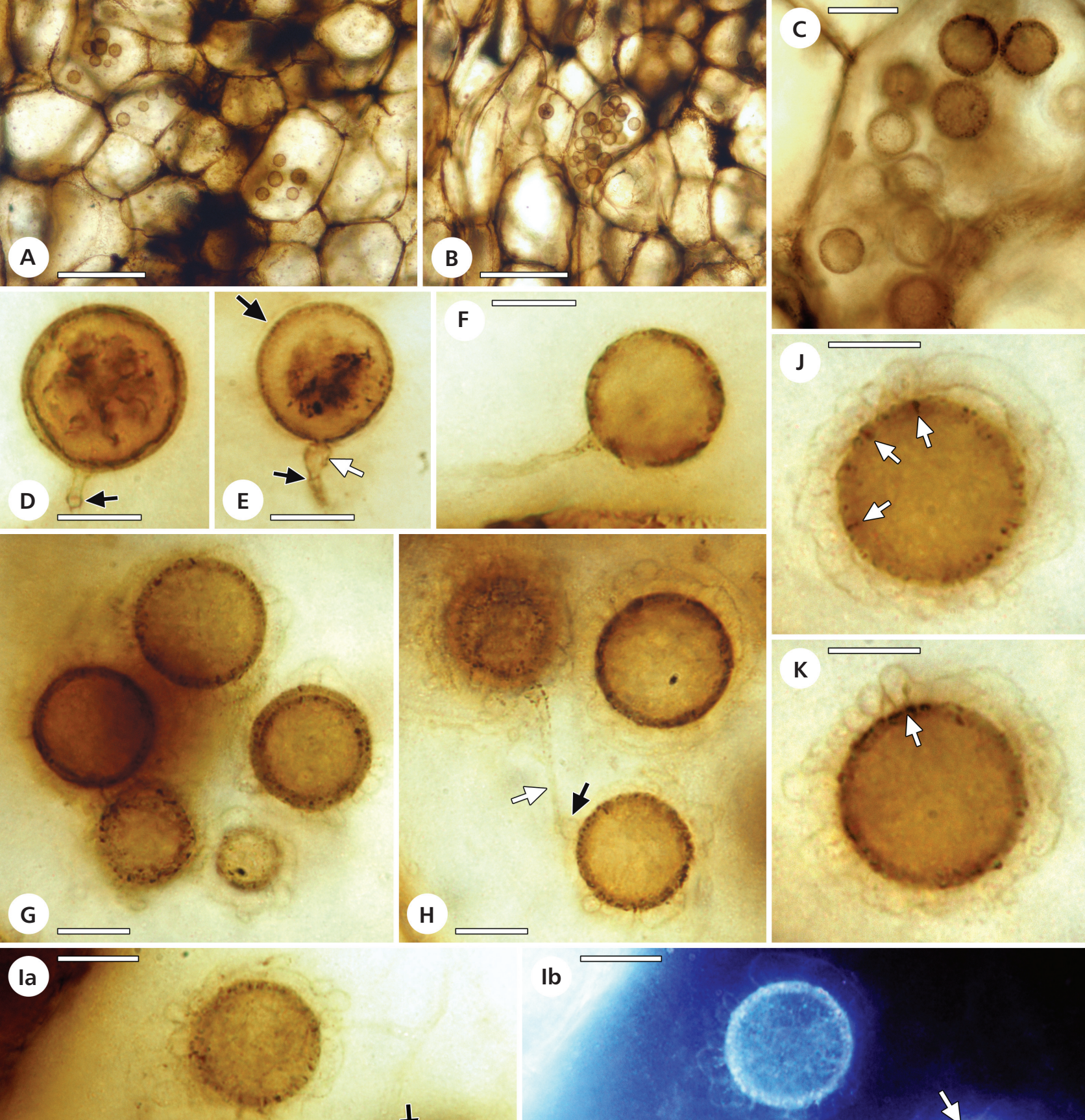

H
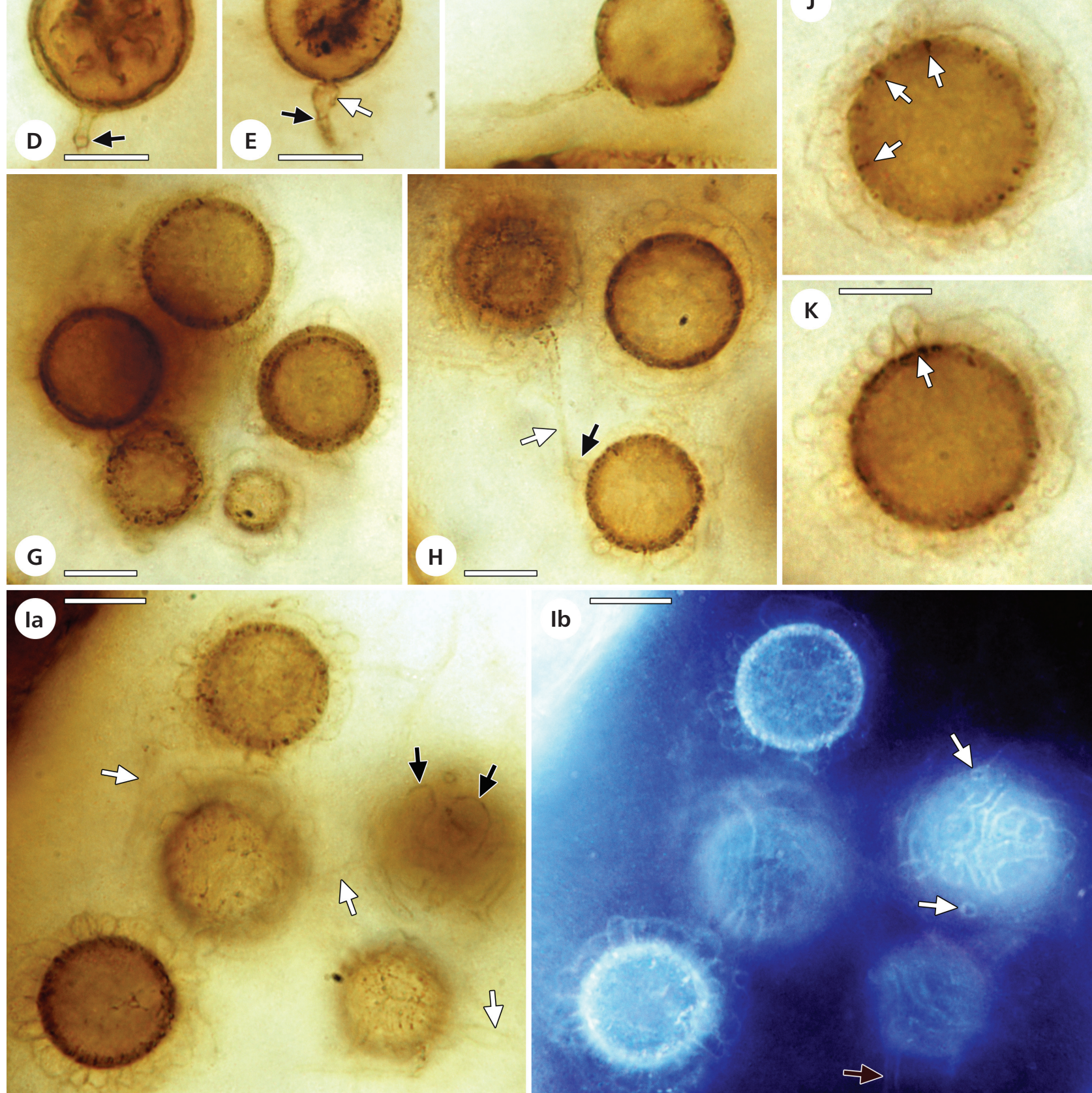

Ib
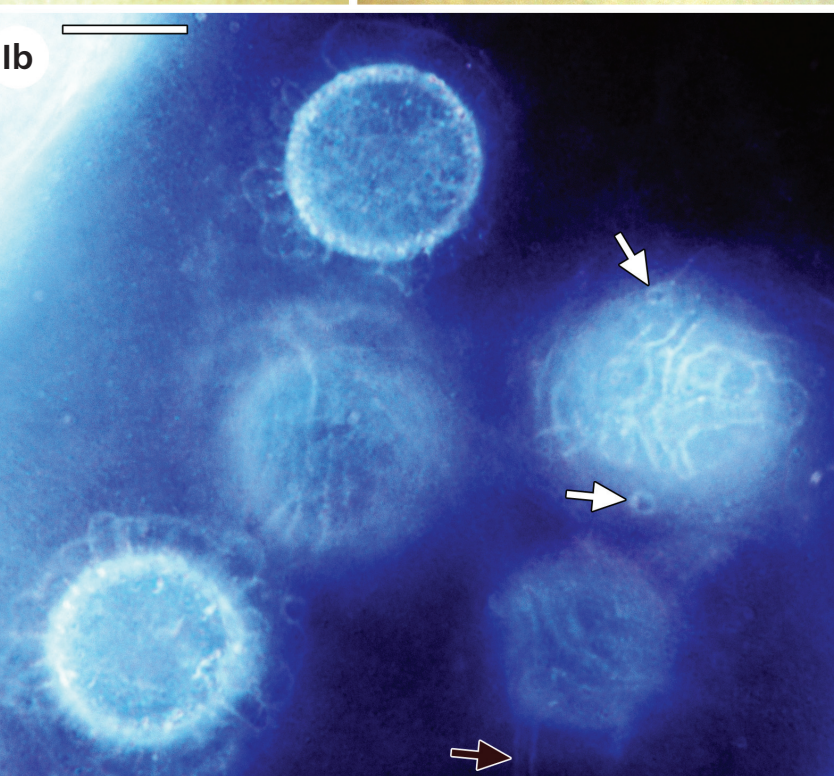

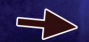


be present (e.g., small black arrows in Fig. 1D and E), and some subtending hyphae additionally possess a bulbous swelling immediately below the reproductive unit (white arrow in Fig. 1E). Tracing the parental hyphae in the clustered mantled specimens is difficult. The small size of the fossils, together with the translucency of all hyphae, render it difficult to determine which of the hyphae in the meshwork surrounding the reproductive units represent the mycelium on which the units were produced and which gave rise to the mantles. For example, the structure marked with arrows in Fig. 1H might represent a subtending hypha (white arrow) with a subterminal bulbous swelling (black arrow), a running hypha that develops into a wide mantle hypha as it reaches the surface of the reproductive unit, or a hyphal branch extending from a mantle hypha and traversing to another reproductive unit.

\section{Discussion}

Fungal reproductive units are abundant and morphologically diverse in the Rhynie chert, and thus may serve as proxy indicators of fungal diversity in this early continental ecosystem. However, the delineation of individual species among the fossils and their precise systematic placement remain challenging tasks because the vast majority of these structures lack features that are diagnostic and consistent (or consistently recognizable) among several specimens (see Krings \& Taylor 2014b). On the other hand, certain fungal reproductive units in the Rhynie chert possess morphological features that are not diagnostic, but still of sufficient distinctiveness to make them identifiable. One of these features is the hyphal mantle.

Hyphal mantles in Rhynie chert fungal reproductive units have initially been noted by Kidston \& Lang (1921). However, these authors did not award this morphological peculiarity any special consideration. More recently, Krings \& Taylor (2013, 2014a) and Krings et al. (2014) provided detailed descriptions and photographic documentations of three different mantled fungal reproductive units from the Rhynie chert. These fossils differ from the form described here with regard to several aspects: First, the new fossils are consistently smaller than all other forms (i.e. 22-32 $\mu \mathrm{m}$ versus $>40 \mu \mathrm{m}$ in diameter, including mantle). Second, the specimens occur as intracellular colonizers of intact land plant tissue, whereas the other forms have been discovered either in the chert matrix or within largely degraded land plant tissue. The fossil material consists of a single thin section preparation, and thus we cannot determine whether the reproductive units were produced within a living plant, or colonization occurred shortly after senescence and fragmentation of the host axis. Third, clustered specimens have not been reported in any of the mantled fungal reproductive structures recorded previously from the Rhynie chert. However, the occurrence in clusters likely represents a preserva- tion bias in which the intact host cells and surrounding tissue may have served some level of protection. The clusters undoubtedly would have become dissociated along with the disintegration of the host tissue. Based primarily on the differences in size, we view the fossils described here as representing part of an organism different from those that produced the other Rhynie chert mantled reproductive units. However, we cannot rule out that the structures represent younger stages, or deviant morphologies or dwarf forms (perhaps resulting from development in confined space) of Zwergimyces vestitus (Kidst. \& W.H. Lang) M. Krings \& T.N. Taylor, another Rhynie chert fungal reproductive unit characterized by a one-layered hyphal mantle composed of branched, irregularly swollen and constricted, densely interlaced hyphae that extend around the circumference of the structure (Krings \& Taylor 2013).

Not all specimens of the new fossil are mantled (Fig. 1D-F). Moreover, mantled and naked specimens may co-occur in the same host cell. One explanation for this condition might be that the host tissue was colonized by two different (but perhaps closely related) fungi, one of which produced naked and the other mantled reproductive units. Adding some support to this hypothesis is the fact that the wall surrounding the central cavity is on average slightly thinner in the naked specimens. Alternatively, all specimens were produced by the same fungus, but represent different types of reproductive units (e.g., dimorphic spores, normal and resting spores/sporangia). Since we have not observed naked and mantled reproductive units in organic connection (i.e. borne on the same parental hypha), and thus cannot determine whether the two forms in fact belong to the same organism, we refrain from formally describing and naming the fossils detailed in this paper.

Krings et al. (2014) suggested that the mantled reproductive units from the Rhynie chert may have systematic affinities with the Glomeromycota or Mucoromycotina (zygomycetous fungi) based on similar features in modern lineages known to produce spores/sporangia with hyphal coverings. The same can be said of the fossils described in this paper, at least of the mantled specimens. Based on the small size, and in the absence of any visible evidence of gametangial fusion, however, it seems more likely that the fossils belong to some lineage of Glomeromycota. However, most glomeromycotan spores are considerably larger than the fossils (e.g., Redecker \& Raab 2006; INVAM homepage). On the other hand, there are several species in the genus Glomus Tul. \& C. Tul. in which spore size is similar to that of the fossils [e.g., (10-)24(-30) $\mu \mathrm{m}$ in Glomus perpusillum Błaszk. \& Kovács and (17-)32(-52) $\mu \mathrm{m}$ in Glomus indicum Błaszk., Wubet \& Harikumar; see Błaszkowski et al. 2009, 2010]. Certain species in the zygomycete genus Mortierella Coem. also produce zygosporangia that are relatively small (e.g., Gams et al. 1972, Kuhlman 1972). Moreover, hyphal mantles or sheaths occur in several Mortierella species (Linnemann 
1941). However, the hyphal coverings in these fungi are usually distinctly more prominent than in the fossil. For example, the zygosporangia of M. alpina var. renispora (Dixon-Stew.) Linnem. are 30-60 $\mu \mathrm{m}$ in diameter and enveloped in a mantle $>200 \mu$ m thick (Linnemann 1941).

Another interesting feature of the new fossils is that specimen clusters are interlaced by a loose meshwork of thin-walled and translucent hyphae (Fig. 1H, Ia), which are interconnected with the mantle hyphae (Fig. 1Ib). This feature is also reminiscent of certain modern Glomeromycota and zygomycetous fungi in which spores/sporangia are produced in clusters or aggregates within a confluent hyphal meshwork, sometimes termed an intrasporocarpic hyphal mycelium or a gleba (e.g., Thaxter 1922, Giovannetti et al. 1991, Yao et al. 1996, Oehl et al. 2014). Groups of mantled fungal reproductive units embedded within a confluent hyphal meshwork have also been observed in several Carboniferous fossils (e.g., Hutchinson 1955, Stubblefield et al. 1983, Krings \& Taylor 2012).

Interestingly, certain structural details might also be used to suggest an alternative interpretation - the fossils represent oogonia of some member of the fungus-like Peronosporomycetes (Oomycota). This suggestion is based on the fact that the oogonia of certain members in the extant Saprolegnia diclina-S. parasitica complex (see DiéguezUribeondo et al. 2007) may sometimes occur in a so-called "birdsnest" condition, in which they are partially or fully enveloped in a mantle-like investment formed by multiple antheridial branches and antheridia (Tiesenhausen 1912, Willoughby 1978, Johnson et al. 2002). Adding some support to this interpretation are the tips of the mantle hyphae in the fossil that are often club-shaped (black arrows in Fig. 1Ia), thus resembling clavate antheridia present in many extant members of Saprolegnia Nees (e.g., Coker 1923, Seymour 1970). Moreover, the narrow radial files of opaque material (arrows in Fig. 1J) might represent pits in the oogonial wall that are secondarily filled with some substance. Pitted oogonia are also known in extant Saprolegnia (Johnson et al. 2002). In addition, some of the fossil mantle hyphae appear to merge with or penetrate the wall of the central cavity (arrow in Fig. 1K). This configuration is suggestive of antheridia producing fertilization tubes that penetrate the oogonium wall. However, there is no evidence suggestive of fertilization tubes or other hyphal components within the lumen of any specimen. Moreover, structures that might represent oospheres or (developing) oospores are absent. While the oospheres of virtually all extant peronosporomycetes are naked structures (Dick 2001), and thus would probably not become preserved in a recognizable form, oospores are bounded by prominent walls, and thus should be preserved in this fossil, precisely as in other Rhynie chert fossils interpreted as Saprolegnia-like peronosporomycete oogonia (Krings et al. 2012, 2013). One might speculate that perhaps the fossils contained only a single plerotic oospore. However, subdivision of the cavity wall into an inner oospore wall and outer oogonium wall is not recognizable in any of the specimens.

The systematic affinities and biological significance of the organisms that are represented by the fungal reproductive units described in this paper remain conjectural. What we do know, however, is that the fossils add to the inventory of fungi that produced mantled reproductive units by the Early Devonian. Moreover, the new fossils attest to the suggestion that mantle morphology, in concert with other structural features, can be used in cataloguing the biological diversity of fungi in the Rhynie chert. Consequently, a first step in understanding the biological significance of these fossils is to report their occurrence, and document a range of features as thoroughly as possible. As more information is accumulated about the Rhynie chert microfungi, some of the complexities that governed this ecosystem during the Early Devonian will likely be more fully understood.

\section{Acknowledgments}

This study was supported by funds from the National Science Foundation (EAR-0949947), the Deutsche Forschungsgemeinschaft (Ke 584/13-2), and the Alexander von Humboldt-Foundation (V-3.FLF-DEU/1064359). We thank U. Projahn, S. Sónyi, and N. Dotzler (Munich) for technical assistance. The paper benefited from the constructive comments and suggestions of H. Kerp (Münster, Germany) and an anonymous referee.

\section{References}

BŁaszkowski, J., Kovács, G.M. \& BalÁzs, T. 2009. Glomus perpusillum, a new arbuscular mycorrhizal fungus. Mycologia 101, 247-255. DOI 10.3852/08-087

BŁaszkowski, J., Wubet, T., Harikumar, V.S., Ryszka, P. \& Buscot, F. 2010. Glomus indicum, a new arbuscular mycorrhizal fungus. Botany 88, 132-143. DOI 10.1139/B09-104

COKER, W.C. 1923. The Saprolegniaceae with notes on other water molds. 201 pp. The University of North Carolina Press, Chapel Hill, NC. DOI 10.5962/bhl.title.6494

Dick, M.W. 2001. Straminipilous fungi. Systematics of the Peronosporomycetes including accounts of the marine straminipilous protists, the Plasmodiophorids and similar organisms. 670 pp. Kluwer Academic Publishers, Dordrecht, Boston, London.

Diéguez-Uribeondo, J., Fregenneda-Grandes, J.M., Cerenius, L., Pérez-Iniesta, E., Aller-Gancedo, J.M., Tellería, M.T., SöDERHÄLl, K. \& MARTín, M.P. 2007. Re-evaluation of the enigmatic species complex Saprolegnia diclina-Saprolegnia parasitica based on morphological, physiological and molecular data. Fungal Genetics and Biology 44, 585-601. DOI 10.1016/j.fgb.2007.02.010

Dighton, J. 2003. Fungi in ecosystem processes. 424 pp. Marcel Dekker Inc., New York. DOI 10.1201/9780203911440

Gams, W., ChiEn, C.Y. \& Domsch, K.H. 1972. Zygospore formation by the heterothallic Mortierella elongata and a related spe- 
cies, M. epigama sp. nov. Transactions of the British Mycological Society 58, 5-13. DOI 10.1016/S0007-1536(72)80065-2

Giovannetti, M., Avio, L. \& Salutini, L. 1991. Morphological, cytological, and ontogenetic characteristics of a new species of vesicular-arbuscular mycorrhizal fungus. Canadian Journal of Botany 69, 161-167. DOI 10.1139/b91-023

Hutchinson, S.A. 1955. A review of the genus Sporocarpon Williamson. Annals of Botany 19, 425-435.

Johnson, T.W., Seymour, R.L. \& Padgett, D.E. 2002. Biology and systematics of the Saprolegniaceae. Published online at: http://dl.uncw.edu/digilib/biology/fungi/taxonomy\%20and\% 20systematics/padgett\%20book [last accessed May 08, 2014]

Kidston, R. \& LANG, W.H. 1921. On Old Red Sandstone plants showing structure, from the Rhynie Cert bed, Aberdeenshire. Part V. The Thallophyta occurring in the peat-bed; the succession of the plants throughout a vertical section of the bed, and the conditions of accumulation and preservation of the deposit. Transactions of the Royal Society of Edinburgh 52, 855-902. DOI 10.1017/S0080456800016045

KRINGS, M. \& TAYLOR, T.N. 2012. Fungal reproductive units enveloped in a hyphal mantle from the Lower Pennsylvanian of Great Britain, and their relevance to our understanding of Carboniferous fungal "sporocarps". Review of Palaeobotany and Palynology 175, 1-9. DOI 10.1016/j.revpalbo.2012.03.001

KRINGS, M. \& TAYLOR, T.N. 2013. Zwergimyces vestitus (Kidston et W.H. Lang) nov. comb., a fungal reproductive unit enveloped in a hyphal mantle from the Lower Devonian Rhynie chert. Review of Palaeobotany and Palynology 190, 15-19. DOI 10.1016/j.revpalbo.2012.11.008

Krings, M. \& TAYLOR, T.N. 2014a. A mantled fungal reproductive unit from the Lower Devonian Rhynie chert that demonstrates Carboniferous "sporocarp" morphology and development. Neues Jahrbuch für Geologie und Paläontologie, Abhandlungen 273, 197-205. DOI 10.1127/0077-7749/2014/0423

KRINGS, M. \& TAYLOR, T.N. 2014b. An unusual fossil microfungus with suggested affinities to the Chytridiomycota from the Lower Devonian Rhynie chert. Nova Hedwigia 99, 403-412.

Krings, M., Taylor, T.N., Dotzler, N. \& HarPer, C.J. 2013. Frankbaronia velata nov. sp., a putative peronosporomycete oogonium containing multiple oospores from the Lower Devonian Rhynie chert. Zitteliana A 53, 23-30.

Krings, M., Taylor, T.N., Taylor, E.L., Hass, H., Kerp, H., Dotzler, N. \& HaRper, C.J. 2012. Microfossils from the Lower Devonian Rhynie chert with suggested affinities to the Peronosporomycetes. Journal of Paleontology 86, 358-367. DOI 10.1666/11-087.1

Krings, M., TAylor, T.N., TAYlor, E.L., Kerp, H. \& Dotzler, N. 2014. First record of a fungal "sporocarp" from the Lower Devonian Rhynie chert. Palaeobiodiversity and Palaeoenvironments 94, 221-227. DOI 10.1007/s12549-013-0135-7

KuHLMAN, E.G. 1972. Variation in zygospore formation among species of Mortierella. Mycologia 64, 325-341. DOI $10.2307 / 3757836$

Linnemann, G. 1941. Die Mucorineen-Gattung Mortierella Coemans. Pflanzenforschung 23, 1-64.

Mark, D.F., Rice, C.M., Fallick, A.E., Trewin, N.H., Lee, M.R., Boyce, A. \& LeE, J.K.W. 2011. ${ }^{40} \mathrm{Ar} /{ }^{39} \mathrm{Ar}$ dating of hydrothermal activity, biota and gold mineralization in the Rhynie hot-spring system, Aberdeenshire, Scotland. Geochimica et Cosmochimica Acta 75, 555-569. DOI 10.1016/j.gca.2010.10.014

Oehl, F., Sánchez-Castro, I., Palenzuela, J., Alves da Silva, G. \& Sieverding, E. 2014. Glomus compressum, a new arbus- cular mycorrhizal fungus from different agro-ecosystems in Central Europe. Nova Hedwigia, in press.

Parry, S.F., Noble, S.R., Crowley, Q.G. \& Wellman, C.H. 2011. A high-precision U-Pb age constraint on the Rhynie chert Konservat-Lagerstätte: time scale and other implications. Journal of the Geological Society, London 168, 863-872. DOI 10.1144/0016-76492010-043

Powell, C.L., Trewin, N.H. \& Edwards, D. 2000. Palaeoecology and plant succession in a borehole through the Rhynie cherts, Lower Old Red Sandstone, Scotland, 439-457. In FRIEND, P.F. \& Williams, B.P.J. (eds) New Perspectives on the Old Red Sandstone. Geological Society of London Publishing House, Bath.

Redecker, D. \& RaAB, P. 2006. Phylogeny of the Glomeromycota (arbuscular mycorrhizal fungi): recent developments and new gene markers. Mycologia 98, 885-895.

DOI 10.3852/mycologia.98.6.885

Rice, C.A. \& AshCroft, W.A. 2004. The geology of the northern half of the Rhynie basin, Aberdeenshire, Scotland. Transactions of the Royal Society of Edinburgh, Earth Sciences 94, 299-308.

Rice, C.M., Trewin, N.H. \& ANDERson, L.I. 2002. Geological setting of the Early Devonian Rhynie cherts, Aberdeenshire, Scotland: An early terrestrial hot spring system. Journal of the Geological Society, London 159, 203-214.

DOI 10.1144/0016-764900-181

Seymour, R.L. 1970. The genus Saprolegnia. Nova Hedwigia 19, $1-124$.

Stubblefield, S.P., Taylor, T.N., Miller, C.E. \& Cole, G.T. 1983. Studies in Carboniferous fungi. II. The structure and organization of Mycocarpon, Sporocarpon, Dubiocarpon, and Coleocarpon (Ascomycotina). American Journal of Botany 70, 1482-1498. DOI 10.2307/2443347

Taylor, T.N., Klavins, S.D., Krings, M., TAYlor, E.L., KerP, H. \& Hass, H. 2004. Fungi from the Rhynie chert: a view from the dark side. Transactions of the Royal Society of Edinburgh, Earth Sciences 94, 457-473.

TAYlor, T.N., KRINGS, M. \& TAYLOR, E.L. 2014. Fossil fungi. $1^{\text {st }}$ edition. 398 pp. Elsevier/Academic Press Inc., Burlington, MA, London.

Thaxter, R. 1922. A revision of the Endogoneae. Proceedings of the American Academy of Arts and Sciences 57, 291-351. DOI $10.2307 / 20025921$

Tiesenhausen, M. von 1912. Beiträge zur Kenntnis der Wasserpilze der Schweiz. Archiv für Hydrobiologie und Planktonkunde 7, 261-308.

Wagner, L., Stielow, B., Hoffmann, K., Petkovits, T., Papp, T., VÁgvölgyi, C., de Hoog, G.S., Verkley, G. \& Voigt, K. 2013. A comprehensive molecular phylogeny of the Mortierellales (Mortierellomycotina) based on nuclear ribosomal DNA. Persoonia 30, 77-93. DOI 10.3767/003158513X666268

Wellman, C.H. 2006. Spore assemblages from the Lower Devonian "Lower Old Red Sandstone" deposits of the Rhynie outlier, Scotland. Transactions of the Royal Society of Edinburgh, Earth Sciences 97, 167-211.

DOI 10.1017/S0263593300001449

Wellman, C.H., Kerp, H. \& Hass, H. 2006. Spores of the Rhynie chert plant Aglaophyton (Rhynia) major (Kidston and Lang) D.S. Edwards, 1986. Review of Palaeobotany and Palynology 142, 229-250. DOI 10.1016/j.revpalbo.2006.04.009

Willoughby, L.G. 1978. Saprolegnias of salmonid fish in Windermere: a critical analysis. Journal of Fish Diseases 1, 51-67. DOI 10.1111/j.1365-2761.1978.tb00005.x 